Tropical Journal of Pharmaceutical Research March 2019; 18 (3): 533-538

ISSN: $1596-5996$ (print); 1596-9827 (electronic)

(C) Pharmacotherapy Group, Faculty of Pharmacy, University of Benin, Benin City, 300001 Nigeria.

\title{
Inhibitory effects of tamoxifen and tanshinone, alone or in combination, on the proliferation of breast cancer cells via activation of p38 MAPK signalling pathway
}

\author{
Haiyan Chen ${ }^{1}$, Yuntao Wang ${ }^{2}$, Xiaoqing Ding ${ }^{1 *}$ \\ ${ }^{1}$ Department of Hematology, Dongfang Hospital Affiliated to Beijing University of Traditional Chinese Medicine, Beijing 100078, \\ ${ }^{2}$ Beijing YuYuanTang Clinic of Traditional Chinese Medicine, Beijing 100021, China
}

*For correspondence: Email: DLajuanashan@yahoo.com; Tel: 0086-010-67689741

Revised accepted: 18 February 2019

\begin{abstract}
Purpose: To investigate the effects of tamoxifen and tanshinone administered individually or in combination, on the proliferation of breast cancer (BC) cells, and the underlying mechanism(s) of action. Methods: Human breast cancer cell lines (SNU-306, SNU-334 and SNU-1528), and normal primary mammary epithelial cell line (HMEC) were cultured at $37^{\circ} \mathrm{C}$ in Dulbecco's modified Eagle's medium (DMEM) supplemented with $5 \%$ fetal bovine serum (FBS), I glutamine $(2 \mathrm{mM})$, penicillin (100 U/m/) and streptomycin $(100 \mu \mathrm{g} / \mathrm{ml})$ in a humidified incubator containing $5 \% \mathrm{CO}_{2}$. Cell proliferation was determined using MTT assay, while real-time quantitative polymerase chain reaction ( $q R T-P C R$ ) was used to determine the expressions of apoptosis-related genes. The expressions of p38 mitogenactivated protein kinases (p38 MAPK) were determined by Western blotting.

Results: There were only few viable cells in tamoxifen- and tanshinone-treated wells, and cell viability was concentration-dependently reduced. Treatment of SNU-306 cells with tamoxifen $(30 \mu \mathrm{M})$ or tanshinone $(20 \mu \mathrm{M})$ alone significantly reduced the expression of Wip1 after $72 \mathrm{~h}$ of incubation, and the level of expression was significantly reduced in SNU-306 cells treated with combination of tamoxifen and tanshinones, relative to those treated with tamoxifen or tanshinone alone $(p<0.05)$. The extent of apoptosis was significantly higher in SNU-306 cells treated with tamoxifen or tanshinone alone or in combination than in control cells $(p<0.05)$. Expressions of Bax, caspase 3 and p53 were significantly higher in SNU-306 cells than in control cells, and were significantly higher in SNU-306 cells treated with combination of tamoxifen and tanshinone than in those treated with tamoxifen or tanshinone alone $(p<$ 0.05). The level of expression of MAPK was significantly higher in SNU-306 cells treated with tamoxifen or tanshinone alone, and in combination treatment, than in control cells $(p<0.05)$.

Conclusion: Tamoxifen and tanshinone administered alone or in combination promote apoptosis in BC cells via mechanisms involving the up-regulation and phosphorylation of MAPK.
\end{abstract}

Keywords: Breast cancer, Tamoxifen, Tanshinone, Expression, Apoptosis

This is an Open Access article that uses a funding model which does not charge readers or their institutions for access and distributed under the terms of the Creative Commons Attribution License (http://creativecommons.org/licenses/by/4.0) and the Budapest Open Access Initiative (http://www.budapestopenaccessinitiative.org/read), which permit unrestricted use, distribution, and reproduction in any medium, provided the original work is properly credited.

Tropical Journal of Pharmaceutical Research is indexed by Science Citation Index (SciSearch), Scopus, International Pharmaceutical Abstract, Chemical Abstracts, Embase, Index Copernicus, EBSCO, African Index Medicus, JournalSeek, Journal Citation Reports/Science Edition, Directory of Open Access Journals (DOAJ), African Journal Online, Bioline International, Open-J-Gate and Pharmacy Abstracts

\section{INTRODUCTION}

Breast cancer (BC) is a malignant tumor and one of the leading causes of death in women globally [1]. The incidence of $B C$ has greatly increased over the last two decades, and endocrinotherapy is the most commonly used method for its treatment [2-4]. The rapid 
invasion and metastasis of $B C$ cells affect its treatment $[5,6]$. Therefore, the development of new treatment strategies for $B C$ is needed to reduce mortalities associated with $\mathrm{BC}$.

Apoptosis, a programmed cell death regulated by the expressions of various molecules such as Bax, p53 and caspases, plays an important role in the regulation of cell proliferation $[7,8]$. Apoptosis is inhibited in prostate carcinoma cells on exposure to $y$-rays via a mechanism involving the up-regulation of wild-type p53-induced phosphatase 1 (Wip1) [9]. The expression of Wip1 is involved in the activation of various pathways [10-13].

This molecule is involved in the development and metastasis of ovarian carcinoma, and its overexpression prevents the cells from undergoing apoptosis [11-14]. Studies have shown that Wip1 is elevated in kidney and nasopharyngeal carcinoma tissues $[15,16]$. It has been reported that targeting of the expression of Wip1 is of therapeutic importance.

The present study investigated the effects of tamoxifen and tanshinone administered alone or in combination, on the proliferation of BC cells, and the underlying mechanism(s).

\section{EXPERIMENTAL}

\section{Materials}

The cell lines SNU-306, SNU-334, SNU-1528 and HMEC were obtained from the American Type Culture Collection (USA); DMEM was a product of Gibco BRL (USA), while Synergy II microplate reader was purchased from Bio-Tek Instruments Inc. (USA). Flow cytometer was purchased from BD Biosciences (USA), and bicinchoninic acid (BCA) assay kit was a product of Sangon Biotech Co., Ltd. Chemiluminescence liquid and autoradiography film were purchased from Bio-Rad Laboratories Inc. (USA). Trizol reagent was a product of Thermo Fisher Scientific Inc. (USA), and SYBR Premix Ex TaqTM II was purchased from Takara Bio Inc. (Japan).

\section{Cell culture}

The SNU-306, SNU-334, SNU-1528 and HMEC were cultured at $37^{\circ} \mathrm{C}$ in DMEM supplemented with $5 \%$ FBS, I-glutamine $(2 \mathrm{mM})$, penicillin $(100 \mathrm{U} / \mathrm{ml})$ and streptomycin $(100 \mu \mathrm{g} / \mathrm{ml})$ in a humidified incubator containing $5 \% \mathrm{CO}_{2}$. Cells in exponential growth phase were used for this study.

\section{MTT assay}

This was used to determine the extent of cell proliferation in SNU-306 cells. The cells $\left(2 \times 10^{4}\right.$ cells/well) at exponential growth phase were seeded into 96-well plates containing DMEM. After $24 \mathrm{~h}$ of incubation, the cells were treated with varied concentrations of tamoxifen or tanshinone $(10-50 \mu \mathrm{M})$ and cultured for $72 \mathrm{~h}$. This was followed by the addition of $20 \mathrm{ml}$ of 0.5 $\%$ MTT solution within $4 \mathrm{~h}$, after which the culture medium was changed. Dimethylsulfoxide (DMSO, $100 \mu \mathrm{l}$ ) was added in drops to each well, and the wells were placed on an oscillator for 10 min to completely dissolve the formazan crystals. The control wells contained culture medium, MTT solution and DMSO only, and were treated same way as the sample wells. Each well was incubated in the dark for $2 \mathrm{~h}$ and absorbance was measured at $495 \mathrm{~nm}$ using synergy II microplate reader. The procedure was performed in triplicate and cell proliferation (C) was calculated as in Eq 1.

$C(\%)=(1-A b s) / A b c \times 100 \%$

where $A b s=$ absorbance of sample well, and $A b c=$ absorbance of control well.

\section{Apoptosis assay}

Apoptosis in SNU-306 cells treated with tamoxifen or tanshinone $(10-50 \mu \mathrm{M})$ was determined using a flow cytometer. The cells were incubated for $72 \mathrm{~h}$, harvested and subsequently treated with HEPES binding buffer containing Annexin V-FITC and propidium iodide $(\mathrm{Pl})$. The treatment was carried out at room temperature for $20 \mathrm{~min}$, after which the cells were placed on a flow cytometer and read. The measurements were performed in triplicate.

\section{Western blotting}

The expressions of Wip I, apoptosis-related genes and p38 MAPK were determined using Western blotting. The cells were lysed using icecold radioimmunoprecipitation assay (RIPA) buffer for $2.5 \mathrm{~h}$. The cell lysate was washed twice with phosphate-buffered saline (PBS) and then treated with Nonidet P-40 (1 \%), Triton X-100 $(0.1 \%), \mathrm{Na}_{2} \mathrm{PO}_{4}(30 \mathrm{mM})$ mixed with sodium orthovanadate $(1 \mathrm{mM})$, Tris- $\mathrm{HCl}(2.5 \mathrm{mM})$, sodium chloride $(100 \mathrm{mM})$, leupeptin $(10 \mu \mathrm{g} / \mathrm{ml})$ and aprotinin for $45 \mathrm{~min}$ at $4{ }^{\circ} \mathrm{C}$. The cell suspension was then centrifuged at $13,000 \mathrm{~g}$ for 25 min at $4{ }^{\circ} \mathrm{C}$. 
The protein concentration of the supernatant was determined using BCA assay kit. A portion of the total cell protein $(35 \mu \mathrm{g})$ from each sample was separated on a $10 \%$ sodium dodecyl sulphate (SDS)-polyacrylamide gel electrophoresis and transferred to a fixed polyvinylidene fluoride membrane at $110 \mathrm{~V}$ and $90^{\circ} \mathrm{C}$ for $120 \mathrm{~min}$. Subsequently, non-fat milk powder $(0.05 \%)$ in Tris-buffered saline containing $0.2 \%$ Tween-20 (TBS-T) was added with gentle shaking at $37{ }^{\circ} \mathrm{C}$ to block non-specific binding of the blot. Thereafter, the blot was incubated with primary antibodies of Wip1, caspase-3, p53, Bax, Bcl-2, p38 MAPK and p-p38 MAPK at a dilution of 1 to 1000 at $4{ }^{\circ} \mathrm{C}$ overnight. Thereafter, the membrane was washed thrice with TBS-T and further incubated with horseradish peroxidaseconjugated goat anti-rabbit $\operatorname{lgG}$ secondary antibody for $1 \mathrm{~h}$ at room temperature. The blot was developed using an x-ray film. Grayscale analysis of the bands was performed using ImageJ analysis software (4.6.2). Respective protein expression levels were normalized to that of $\beta$-actin, used as a standard reference.

\section{qRT-PCR}

Total RNAs were isolated from the treated and control cells using Trizol reagent. The RNAs were reverse-transcribed to cDNAs using random primers at $45{ }^{\circ} \mathrm{C}$ for $2 \mathrm{~h}$. The samples were heated at $95{ }^{\circ} \mathrm{C}$ for $10 \mathrm{~min}$, and PCR amplification of the reverse transcribed reaction mixture was carried out using $20 \mu \mathrm{l}$ reaction mixture and equal volume of SYBR Premix Ex TaqTM II. The reaction mixture also contained cDNA $(2 \mu \mathrm{l})$, mixture of forward and reverse primers $(0.8 \mu \mathrm{l})$ and double-distilled $\mathrm{H}_{2} \mathrm{O}(6 \mu \mathrm{l})$. The PCR conditions were: pre-denaturation at 95 ${ }^{\circ} \mathrm{C}$ for $30 \mathrm{~s}$, denaturation at $95{ }^{\circ} \mathrm{C}$ for $3 \mathrm{~s}$, annealing at $60{ }^{\circ} \mathrm{C}$ for $34 \mathrm{~s}$, and 40 cycles. The procedure was performed in triplicate. Relative expression was quantified using $2^{\Delta \Delta} \mathrm{Cq}$ method, and $\beta$-actin gene was used as internal reference.

\section{Statistical analysis}

Data are expressed as mean $\pm S D$, and the statistical analysis was performed using SPSS (17.0). Groups were compared using Student $t$ test, and values of $p<0.05$ were considered statistically significant.

\section{RESULTS}

\section{Effect of tamoxifen and tanshinone on SNU- 306 cell viability}

There were only few viable cells in tamoxifenand tanshinone-treated wells, and cell viability was concentration-dependently reduced. Maximum decrease in cell viability was obtained with tamoxifen and tanshinone at 30 and $20 \mu \mathrm{M}$, respectively, and cell proliferations at these concentrations were 62 and $58 \%$, respectively. However, combination of tamoxifen and tanshinone reduced the proliferation of SNU306 cells to $29 \%(p<0.05$; Figure 1$)$.

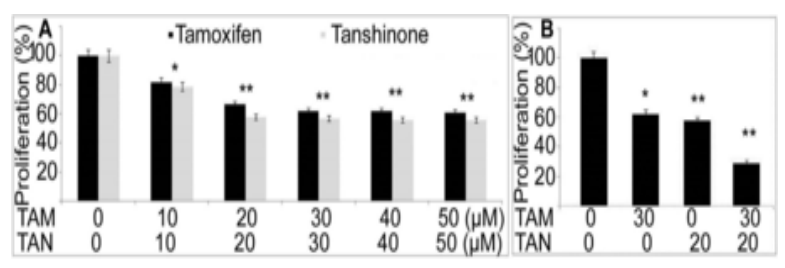

Figure 1: Effect of tamoxifen and tanshinone on the proliferation of SNU-306 cell. A: Proliferation of SNU-306 cells following treatment with varied concentration of tamoxifen or tanshinone (10 - 50 $\mu \mathrm{M})$; B: Proliferation of SNU-306 cells following treatment with combination of tamoxifen and tanshinone. ${ }^{*} p<0.05$ and ${ }^{* *} p<0.01$, when compared to control cells

\section{Expressions of Wip1 in untreated BC and HMEC cells}

Results of qRT-PCR and Western blotting showed that the level of expression of Wip1 was significantly higher in BC cells than in HMEC cells $(p<0.05$; Figure 2).

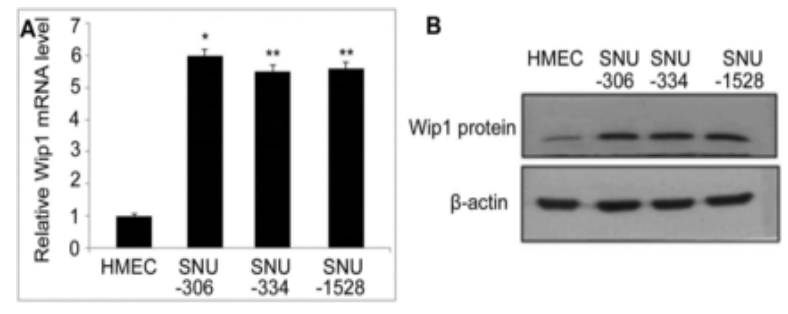

Figure 2: Expressions of Wip1 in BC and HMEC cells. A: Expression of Wip1 in BC and HMEC cells as determined using qRT-PCR; B: Expression of Wip1 in BC and HMEC cells as determined using Western blotting. " $p<0.05$ and ${ }^{* *} p<0.01$, when compared to HMEC cells

\section{Effects of tamoxifen and tanshinone on the expression of Wip1 in SNU-306 cells}

Treatment of SNU-306 cells with tamoxifen (30 $\mu \mathrm{M})$ or tanshinone $(20 \mu \mathrm{M})$ alone significantly reduced the expression of Wip1; expression level of Wip1 was significantly reduced in SNU306 cells treated with combination of tamoxifen and tanshinones, when compared with those treated with tamoxifen or tanshinone alone $(p<0.05)$. These results are shown in Figure 3. 


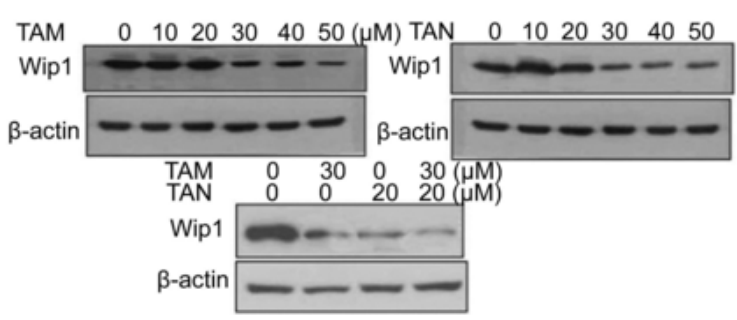

Figure 3: Expression of Wip1 in tamoxifenand tanshinone-treated SNU-306 cells

\section{Effects of tamoxifen and tanshinone treatment on cell apoptosis}

As shown in Figure 4, the extent of apoptosis was significantly higher in SNU-306 cells treated with tamoxifen or tanshinone alone or in combination than in control cells $(p<0.05)$. Apoptosis in SNU-306 cells treated with tamoxifen or tanshinone alone, or in combination were $36.65,40.98$ and $67.32 \%$, respectively, while that of control was $2.43 \%$.
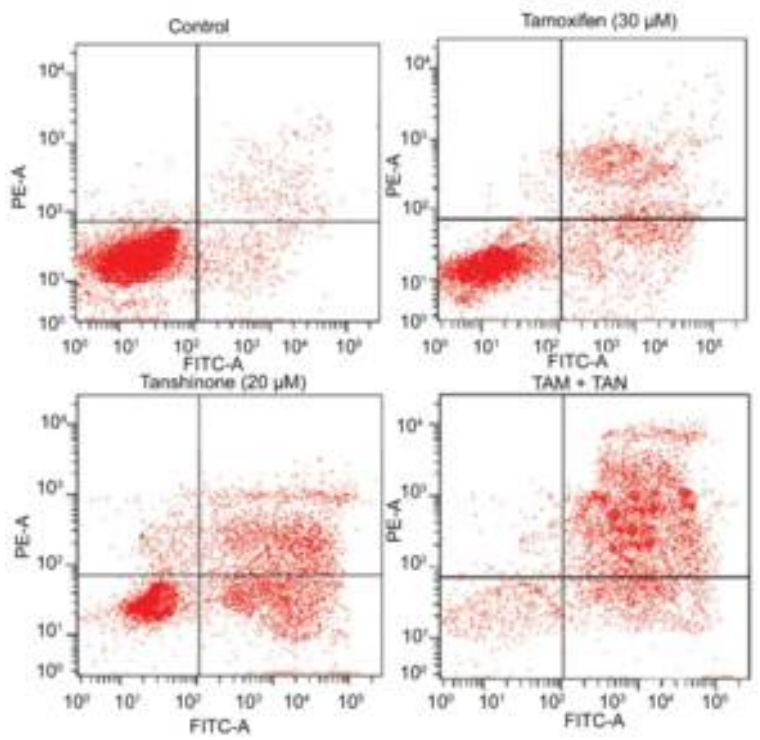

Figure 4: Effects of tamoxifen and tanshinone on apoptosis of SNU-306 cells. ${ }_{* *} P<0.05,{ }^{\star *} p<0.01$, and ${ }^{* *} p<0.001$, when compared to control cells

\section{Effects of tamoxifen and tanshinone on expressions of apoptosis-related genes}

The expressions of Bax, caspase 3 and p53 were significantly higher in SNU-306 cells than in control cells, and significantly higher in SNU306 cells treated with combination of tamoxifen and tanshinone than in those treated with tamoxifen or tanshinone alone $(p<0.05)$. However, the expression of $\mathrm{Bcl}-2$ was significantly lower in the different treatment groups than in control cells $(p<0.05$; Figure 5$)$.

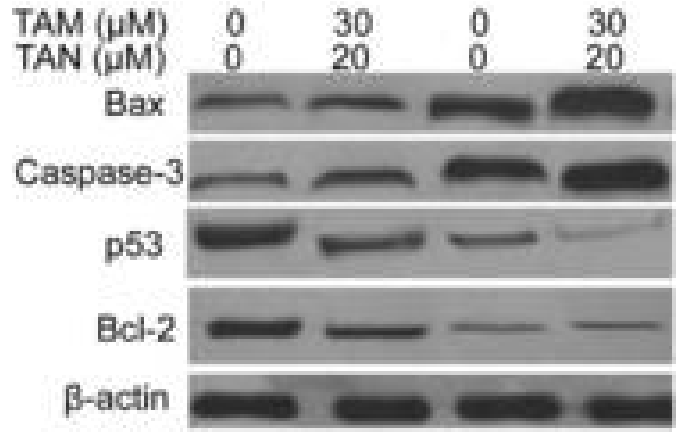

Figure 5: Up-regulation of apoptosis-related genes in SNU-306 cells treated with tamoxifen and tanshinone

\section{Effects of tamoxifen and tanshinone treatment on p38 MAPK}

The level of expression of MAPK was significantly higher in SNU-306 cells treated with tamoxifen or tanshinone alone or in combination than in control cells $(p<0.05)$. However, there were no significant differences in the expression levels of ERK and JNK between SNU-306 and control cells. These results are shown in Figure 6.

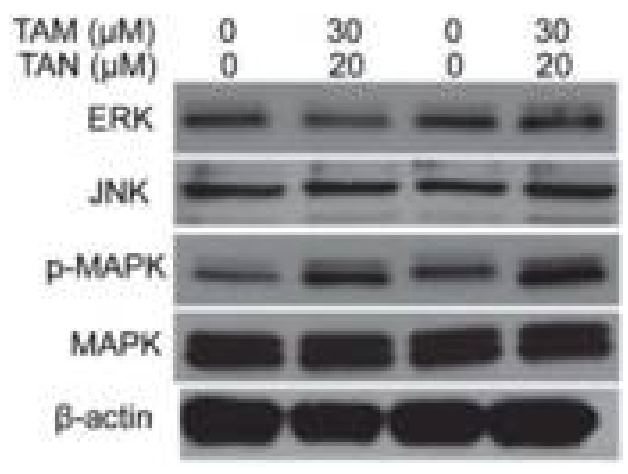

Figure 6: Expression levels of MAPK, ERK and JUN in SNU-306 cells

\section{DISCUSSION}

Inhibition of Wip1 expression using UV radiation has been reported to play a key role in the induction of cell apoptosis [17]. Cultures of BC cells exhibit marked increases in apoptosis on exposure to CCT007093, an inhibitor of Wip1 [17].

The present study investigated the effects of tamoxifen and tanshinone administered alone or in combination on the proliferation of $\mathrm{BC}$ cells, and the underlying mechanism(s). Tamoxifen or tanshinone administered alone or in combination significantly inhibited proliferation of $B C$ cells, and the inhibition of proliferation was significantly higher in BC cells treated with combination of tamoxifen and 
tanshinone. In human chromosomes, Wip1 exists as a serine/threonine phosphatase whose expression is upregulated in various types of cancers [18-21]. Overexpression of Wip1 causes down-regulation of cell apoptosis $[22,23]$. Studies involving neuronal tissues have shown that the suppression of Wip1 expression by exposure of nerve cells to manganese significantly enhances apoptosis [1]. It has also been reported that the expression of Wip1 in breast tumor is significantly higher than in normal tissues [24]. In this study, the expression of Wip1 was significantly higher in BC cells than in normal cells, an indication that Wip1 may promote the proliferation of $\mathrm{BC}$ cells.

In cancer cells, there are usually significant increases in the expressions of factors which inhibit apoptosis, and significant reductions in the expressions of pro apoptotic molecules $[22,23]$. In prostate carcinoma cells, exposure to $Y$ rays causes up-regulation of Wip1 which in turn catalyses the translocation of Bax to mitochondrion, thereby inhibiting cell apoptosis [9]. In rats, inhibition of Wip1 overexpression has been reported to increase the levels of p53 and Bax, thereby enhancing cell apoptosis [14].

Regulation of the expressions of pro and antiapoptotic factors has been reported to have immense importance in the treatment of cancers. In this study, the population of apoptotic cells increased significantly on exposure of $\mathrm{BC}$ cells to tamoxifen or tanshinone alone or in combination, and the combination increased apoptosis more than when the drugs were administered alone. Expressions of Bax, caspase 3 and p53 were significantly higher in SNU-306 cells than in control cells, and were significantly higher in SNU-306 cells treated with combination of tamoxifen and tanshinone than in those treated with tamoxifen or tanshinone alone. However, the expression of $\mathrm{Bcl} 2$ was significantly lower in the different treatment groups than in control cells.

The phosphorylation of p38 MAPK by various chemotherapeutic agents has been reported to inhibit tumor growth and development via a mechanism involving cell cycle arrest [25 - 28]. In this study, the level of expression of MAPK was significantly higher in SNU-306 cells treated with tamoxifen or tanshinone alone or in combination than in control cells. However, there were no significant differences in the expressions levels of ERK and JNK between SNU-306 and control cells. These results suggest that tamoxifen and tanshinone may exert anti-apoptotic effect via the up-regulation and phosphorylation of MAPK. It is possible that the down-regulation of Wip1 inhibits growth and development of $\mathrm{BC}$ cells by activating MAPK [24].

\section{CONCLUSION}

Tamoxifen and tanshinone administered alone or in combination promotes apoptosis in BC cells via mechanisms involving the up-regulation and phosphorylation of MAPK.

\section{DECLARATIONS}

\section{Acknowledgement}

Support from Young Scientists Fund of the National Natural Science Foundation of China (no. 81503302) and Beijing University of Traditional Chinese Medicine, 1166 Development Program for Junior Scientists (no. 030903010332) is acknowledged.

\section{Conflict of interest}

No conflict of interest is associated with this work.

\section{Contribution of authors}

We declare that this work was done by the authors named in this article and all liabilities pertaining to claims relating to the content of this article will be borne by the authors. Haiyan Chen and Yuntao Wang performed all the experimental work and carried out the literature survey, Xiaoqing Ding designed the study and wrote the paper. The paper was approved by all the authors for publication.

\section{REFERENCES}

1. Zhu W, Harvey S, Macura KJ, Euhus DM, Artemov D. Invasive breast cancer preferably and predominantly occurs at the interface between fibroglandular and adipose tissue. Clin Breast Cancer 2017; 17: e11-e18.

2. Halpern MT, Spain P, Holden DJ, Stewart A, McNamara EJ, Gay G, Das IP, Clauser S. Improving quality of cancer care at community hospitals: Impact of the National Cancer Institute Community Cancer Centers Program pilot. J Oncol Pract 2013; 9: e298 e304.

3. Krzysiek J, Wiatr J, Milewicz T, Wyroba J, Krzyczkowska Sendrakowska M, Galicka Latała D, Rajtar Ciosek A, Kacalska Janssen O, Zmaczyński A, Stochmal E. The incidence of neoplasm in women using contraceptives. Przegl Lek 2010; 67: 519522 (In Polish).

4. Hoffmann J, Sommer A. Steroid hormone receptors as targets for the therapy of breast and prostate cancer recent advances, mechanisms of resistance, and new 
approaches. J Steroid Biochem Mol Biol 2005; 93: 191 200.

5. Ottewell $P D$, O'Donnell L, Holen I. Molecular alterations that drive breast cancer metastasis to bone. Bonekey Rep 2015; 4: 643

6. Khajah MA, Almohri I, Mathew PM, Luqmani YA. Extracellular alkaline $\mathrm{pH}$ leads to increased metastatic potential of estrogen receptor silenced endocrine resistant breast cancer cells. PLoS One 2013; 8: e76327.

7. Chen $Y$, Bieber MM, Teng NN. Hedgehog signaling regulates drug sensitivity by targeting $A B C$ transporters $A B C B 1$ and $A B C G 2$ in epithelial ovarian cancer. Mol Carcinog 2014; 53: 625634.

8. Zhang $P$, Jia R, Ying L, Liu B, Qian G, Fan X, Ge $S$. WWOX mediated apoptosis in A549 cells mainly involves the mitochondrial pathway. Mol Med Rep 2012; 6: 121124.

9. Song JY, Ryu SH, Cho YM, Kim YS, Lee BM, Lee SW, Choi J. Wip1 suppresses apoptotic cell death through direct dephosphorylation of $B A X$ in response to $V$ radiation. Cell Death Dis 2013; 4: e744.

10. Fiscella $M$, Zhang $H$, Fan $S$, Sakaguchi $K$, Shen $S$, Mercer WE, Vande Woude GF, O'Connor PM, Appella E. Wip1, a novel human protein phospahtase that is induced in response to ionizing radiation in a p53 dependent manner. Proc Natl Acad Sci USA 1997; 94: 60486053.

11. Hirasawa A, Saito Ohara F, Inoue J, Aoki D, Susumu N, Yokoyama $T$, Nozawa $S$, Inazawa J, Imoto I. Association of 17q21 q24 gain in ovarian clear cell adenocarcinomas with poor prognosis and identification of PPM1D and APPBP2 as likely amplification targets. Clin Cancer Res 2003; 9: 19952004.

12. Richter M, Dayaram $T$, Gilmartin AG, Ganji $G$, Pemmasani SK, Van Der Key $H$, Shohet JM, Donehower LA, Kumar R. WIP1 phosphatase as a potential therapeutic target in neuroblastoma. PLoS One 2015; 10: e0115635.

13. Tang YL, Liu X, Gao SY, Feng $H$, Jiang YP, Wang SS, Yang J, Jiang J, Ma XR, Tang YJ. WIP1 stimulates migration and invasion of salivary adenoid cystic carcinoma by inducing MMP 9 and VEGF C. Oncotarget 2015; 6: 90319044.

14. Ma X, Han J, Wu Q, Liu H, Shi S, Wang C, Wang Y, Xiao $J$, Zhao J, Jiang J, Wan C. Involvement of dysregulated Wip1 in manganese induced p53 signaling and neuronal apoptosis. Toxicol Lett 2015; 235: 1727.

15. Sun GG, Zhang J, Ma XB, Wang YD, Cheng YJ, Hu WN. Overexpression of Wild Type p53 Induced Phosphatase 1 confers poor prognosis of patients with Nasopharyngeal Carcinoma. Pathol Oncol Res 2015; 21: 283291.

16. Sun GG, Wang YD, Liu Q, Hu WN. Expression of Wip1 in kidney carcinoma and its correlation with tumor metastasis and clinical significance. Pathol Oncol Res 2015; 21: 219224.

17. Lee JS, Park JR, Kwon OS, Kim H, Fornace AJ Jr, Cha HJ. Off target response of a Wip1 chemical inhibitor in skin keratinocytes. J Dermatol Sci 2014; 73: 125134.

18. Rauta J, Alarmo EL, Kauraniemi P, Karhu R, Kuukasjärvi $T$, Kallioniemi $A$. The serine threonine protein phosphatase PPM1D is frequently activated through amplification in aggressive primary breast tumours. Breast Cancer Res Treat 2006; 95: 257263.

19. Fuku T, Semba S, Yutori H, Yokozaki H. Increased wild type p53 induced phosphatase 1 (Wip1 or PPM1D) expression correlated with downregulation of checkpoint kinase 2 in human gastric carcinoma. Pathol Int 2007; 57: 566571

20. Castellino RC, De Bortoli M, Lu X, Moon SH, Nguyen TA, Shepard MA, Rao PH, Donehower LA, Kim JY. Medulloblastomas overexpress the p53 inactivating oncogene WIP1/PPM1D. J Neurooncol 2008; 86: 245 256.

21. Saito Ohara F, Imoto I, Inoue J, Hosoi H, Nakagawara A, Sugimoto T, Inazawa J. PPM1D is a potential target for 17q gain in neuroblastoma. Cancer Res 2003; 63: 1876 1883.

22. Lowe J, Cha H, Lee MO, Mazur SJ, Appella E, d FornaceA J Jr. Regulation of the Wip1 phosphatase and its effects on the stress response. Front Biosci (Landmark Ed) 2012; 17: 14801498.

23. Zhang XP, Liu F, Wang W. Two phase dynamics of $p 53$ in the DNA damage response. Proc Natl Acad Sci USA 2011; 108: 89908995.

24. Yang $D H$, He JA, Li J, Ma WF, Hu XH, Xin SJ, Duan ZQ. Expression of proto oncogene Wip1 in breast cancer and its clinical significance. Zhonghua Yi Xue Za Zhi 2010; 90: 519522

25. Wang HY, Liu ZS, Qiu L, Guo J, Li YF, Zhang J, Wang TJ, Liu XD. Knockdown of Wip1 enhances sensitivity to radiation in hela cells through activation of p38 MAPK. Oncol Res 2014; 22: 225233

26. Tallman M, Lo Coco F, Barnes G, Kruse M, Wildner R, Martin $M$, Mueller $U$, Tang $B$. Cost effectiveness analysis of treating acute promyelocytic leukemia patients with arsenic trioxide and retinoic acid in the United States. Clin Lymphoma Myeloma Leuk 2015; 15: 771777.

27. Shepshelovich $D$, Oniashvili $N$, Parnes $D$, Klein $A$, Muchtar E, Yeshaya J, Aviram A, Rabizadeh E, Raanani $P$. Acute promyelocytic leukemia with isochromosome $17 q$ and cryptic PML RARA successfully treated with all trans retinoic acid and arsenic trioxide. Cancer Genet 2015; 208: 575579.

28. Yoda A, Toyoshima K, Watanabe Y, Onishi N, Hazaka Y, Tsukuda Y, Tsukada J, Kondo T, Tanaka Y, Minami Y. Arsenic trioxide augments Chk2/p53 mediated apoptosis by inhibiting oncogenic Wip1 phosphatase. J Biol Chem 2008; 283: 1896918985. 